Taking stock of existing data access regimes 


\title{
Data access rules: The role of contractual unfairness control of (consumer) contracts
}

\author{
Michael Grünberger"
}

\section{A. (Responsive) Contract law shall be Queen}

Legal paradigms express the 'implicit images of one's own society, giving a certain perspective to the practice of both legislation and the law's application'. ${ }^{1}$ Paradigms shape the construction and the interpretation of legal rules and principles as 'a response to the challenges of a social situation perceived in a certain way'. ${ }^{2}$ This applies in particular to the current debates within data and information law. Twenty years ago the movement from ownership to access was heralded. ${ }^{3}$ The shift in business models from the single (digital) transfer to continuous accessibility as well as the rise of the 'sharing economy' are two trends that have shaped the (digital) economy and they both appear to vindicate the prominence of the access paradigm. Furthermore, the most recent developments regarding machinegenerated data seem to support the prevalence of the access paradigm: The discussion started off with the proposal of an exclusive 'data producer's right' (Datenerzeugerrecht $)^{4}$ and, eventually, led to the advocacy of a 'data ownership right' (Dateneigentumsrecht). ${ }^{5}$ However, it quickly took a very

* I would like to thank my doctoral student Katharina Wunner for her valuable input and my student assistants Jana Ebersberger and Daniel Neubauer for their support in adjusting the paper to the formal prerequisites.

1 Jürgen Habermas, Faktizität und Geltung ( $4^{\text {th }}$ edn, Suhrkamp 1994) 468.

2 Habermas (n. 1) 468.

3 Jeremy Rifkin, The Age of Access (Pinguin Business Library 2000).

4 Herbert Zech, 'Daten als Wirtschaftsgut - Überlegungen zu einem "Recht des Datenerzeugers"' (2015) Computer und Recht 137; Herbert Zech, 'Data as a Tradable Commodity' in Alberto de Franceschi (ed.), European Contract Law and the Digital Single Market (Intersentia 2016) 51, 74.

5 Marc Amstutz, 'Dateneigentum', (2018) 218 Archiv für die civilistische Praxis 438; Karl-Heinz Fezer, 'Repräsentatives Dateneigentum - Ein zivilgesellschaftliches Bürgerrecht' (2018) <www.kas.de/c/document_library/get_file?uuid=f828a351-a2f611c1-b720-1 aa08eaccff9\&groupId=252038> accessed 31 August 2020; Karl-Heinz Fezer, 'Data Ownership of the People' (2017) 9 Zeitschrift für Geistiges Eigentum 356. 
different turn against the introduction of new intellectual property rights and in favour of introducing access rules. ${ }^{6}$ The policy reasons behind this shift are rather simple: Markets can 'develop with relatively little legal exclusivity where access can effectively be controlled by technical means. Factual exclusivity has the potential of forcing parties into negotiations and can trigger transactions in very similar ways as in the case of intellectual property'. ${ }^{7}$ This description captures one of the two pillars of the current status quo in the data economy: the facticity of control over data access (Faktizität der Datenzugangskontrolle). The de facto control over data generated and secured by means of technically structured processes does not entail any notion of normative ownership. ${ }^{8}$ But 'the recognition of a de facto property over industrial dataset is a non-neutral allocative choice'. 9 This recognition rests on a normative foundation. The second pillar upon which the status quo of the data economy is built is the contract between the parties. It is precisely this contract that normatively allocates the control, and therefore the use of the data among the parties. Thus, the contract legally secures the de facto control of the producer of the data-generating device or a data service provider. For the purpose of this paper I assume that the contract privileges this party. Henceforth I will call this party the 'data holder' or, synonymously, 'data controller'. Granted, contractual language with "which the data holder claims "ownership" in the data cannot result in ownership rights as rights in rem [and] as a matter of privacy of contract, such stipulation can only produce (inter partes) effects among the contracting parties'. ${ }^{10}$ But the contractual allocation of the data to the data

6 Josef Drexl and others, 'Data Ownership and Access to Data - Position Statement of the Max Planck Institute for Innovation and Competition of 16 August 2016 on the Current European Debate' <https://papers.ssrn.com/sol3/papers.cfm?abstra ct_id=2833165 $>$ accessed 31 August 2020.

7 Josef Drexl, 'Designing Competitive Markets for Industrial Data' (2017) 8 Journal of Intellectual Property, Information Technology and E-Commerce Law 257, para. 69.

8 See Daria Kim, 'No One's Ownership as the Status Quo and a Possible Way Forward: A Note on the Public Consultation on Building a European Data Economy', (2017) Gewerblicher Rechtsschutz und Urheberrecht Internationaler Teil 697, 702.

9 See Francesco Mezzanotte, 'Access to Data: The Role of Consent and the Licensing Scheme' in Sebastian Lohsse, Reiner Schulze and Dirk Staudenmeyer (eds), Trading Data in the Digital Economy: Legal Concepts and Tools (Nomos 2017) 159, 167.

10 Josef Drexl, 'Data Access and Control in the Era of Connected Devices. Study on Behalf of the European Consumer Organisation BEUC' (2018) 29-30<www.beuc 
holder carries considerable normative weight, because it is prima facie the only legal justification for the facticity of control over data access.

The introduction of an (intellectual) property right would not substantially alter this picture, regardless of the (problematic) issue ${ }^{11}$ to whom the right should be granted: If it were attributed to the party which already enjoys de facto control over the data, this normative choice would provide a third pillar to the current allocation of the data use, thus further strengthening the data holder's legal position. If, as proposed for example in the model of data ownership, the right were initially vested in the end-user of the data-producing artefact, the introduction of a property right would add nothing but transaction costs: The contract the end-user enters into either with the producer or, as is the case in end-user licence agreements, with the service provider of the artefact, would, in the light of the respective bargaining power and informational and technological asymmetries between the parties, most likely reallocate the data usage rights to the de facto data holder. Enabling this mechanism is but the purpose of introducing property rights for immaterial goods in the first place. ${ }^{12}$ Furthermore, property rights are (at present) considered too rigid a corset for effectively regulating dynamic markets. Thus, contractually secured de facto access currently not only provides an equivalent regulatory tool but may even be superior due to its flexibility. Regardless of the perspective, the status quo can be summed up as follows: Contract is King - and freedom of contract the main self-regulatory instrument within the current data economy. Hence the governing paradigm within the data economy appears to be that of (de facto) ownership and (contractual) control, regardless of all the talk about access.

In this paper I would like to challenge this paradigm and to dethrone the 'King'. In his place I would like to implement a responsive contract law as the new Queen. The main feature of responsive contract law is that it conceptualises its instruments from a sociological perspective and conceives of the parties' subjective rights regarding their social functions within the law's social environment (infra C.I.1.a). I will propose the argument that the unfairness control of contractual terms in both business-to-con-

.eu/publications/beuc-x-2018-121_data_access_and_control_in_the_area_of_conn ected_devices.pdf $>$ accessed 31 August 2020.

11 For the problems associated with the ownership of a data IP right, see Drexl (n. 7) 257, para. 106; Herbert Zech, 'Building a European Data Economy' (2017) 9 Zeitschrift für Geistiges Eigentum 317, 324-325.

12 Hanns Ullrich, 'Lizenzkartellrecht auf dem Weg in die Mitte' (1996) Gewerblicher Rechtsschutz und Urheberrecht Internationaler Teil 555, 565-566. 
sumer (B2C) and business-to-business (B2B) relations can from the outset be designed to become an adequate access rule in multilateral contract networks to effectively enforce individual access rights of end-users to co-generated data.

My argument is rather simple: Because the data holder justifies her de facto exclusivity through contract, it becomes contract law's responsibility to check on the normative foundation of the de facto technological standard by applying an unfairness control to the contractual terms at issue. That is why the unfairness control functions as an 'access rule'. The unfairness control is not necessarily dependent on the availability of supplementary provisions in contract law. The benchmark for the unfairness control is the collective knowledge gathered by the private actors. Enhancing the knowledge-gaining process of private ordering through contract law is at the core of my proposal. My model operates on a (rebuttable) presumption that contractual standard terms are not unfair if they are an integral part of model contracts, codes of conduct or best practices that in turn are compliant with certain requirements of procedural justice. If the presumption is successfully rebutted, the access-restricting contract clause is unfair and therefore invalid. If the contractual terms and conditions fail to meet the unfairness test, the contract will turn against the data holder: The technological de facto standard regarding exclusivity is in violation of contract law's normative standards regarding the usability of the data at issue. Hence, the facticity of the data holder's control of the data not only lacks a normative justification but runs afoul of contract law's principles regarding fair data allocation and access to co-generated data. To remedy the normative deficit of the facticity regarding data control, contract law demands that data access be reallocated to the other party. As a result, responsive contract law provides a contractual claim of the end-user against the data holder to actively enable access to individual-level data co-generated by the end-user or within the end-user's responsibility. Thus, the unfair terms control is an additional regulatory instrument to enhance data access in the data economy and it should be part of the Member States' and, eventually, the European regulator's toolbox.

The paper will focus on machine-generated data. Having said that, it must acknowledge the fact that because of the multitudes of data-generating contexts it is difficult to impossible to sufficiently distinguish purely machine-generated data from personal data within the meaning of Article 4(1) General Data Protection Regulation (GDPR). An environmentally sensitive contract law solution must therefore address the overlap between non-personal and personal data within machine-generated data (infra B.II). The paper will proceed in three steps: First, I will briefly describe the regu- 
latory problem posed by the need of data access in the data economy and argue to consider contract law as an additional regulatory tool (B). Second, I will sketch a proposal based on the established unfairness control and enhance the latter with procedural elements in order to facilitate knowledge gaining (C). Third, I will address two of the most obvious challenges of this model (D). The paper will end with some concluding remarks (E).

\section{B. The regulatory problem: enabling data access under fair terms}

\section{Negative impacts of the status quo}

The European Commission has been aware of the access issue regarding data generated by machines or processes (machine-generated data): 'In order to extract the maximum value from this type of data, market players need to have access to large and diverse datasets. However, this becomes more difficult to achieve if the generators of the data keep it to themselves.' 13 The situation is aggravated if the user is 'prevented by the manufacturer from authorising usage of the data by another party'. ${ }^{14}$ The status $q u o$ is the de facto control of data by the data controller, combined with the contractual justification of this data allocation, regularly accompanied by contractual terms governing access to the data and prohibiting the transfer of the data to third parties. This is a regulatory problem from at least two perspectives: ${ }^{15}$ From a competition perspective, the status quo leads to negative innovation effects, making market access more difficult and increasing lock-in effects. Additionally, the status quo also has negative effects on the contractual balance of interests: There is a serious risk of unequal negotiating positions between the manufacturer or service provider on the one hand and the end-user of the products on the other hand. This may result in unfair standard contract terms which, overall, significantly increase the transaction costs for structurally weaker parties - consumers or SMEs.

The Commission has identified one particular constellation where the aforementioned negative impacts on both competition and contractual equity might come into play: '[I]n some cases manufacturers, companies offering services or other market players holding data keep the data generat-

13 Communication of the European Commission, 'Building a European Data Economy' $\operatorname{COM}(2017) 9$ final, 8.

14 European Commission (n. 13) $\operatorname{COM}(2017) 9$ final, 10.

15 See European Commission (n. 13) COM(2017) 9 final, 8-11. 
ed by their machines or through their products and services for themselves, thus potentially restricting reuse in downstream markets. ${ }^{16}$ An example might be helpful to illustrate this point: ${ }^{17}$ Gämmerler is a southern German engineering company for components and complete systems for the printing industry. They offer a smart monitoring service to their (professional) customers to avoid unplanned downtimes of the machines. Gämmerler has partnered with the operator of a service platform (Siemens) to collect and analyse usage data on their machines, which are distributed worldwide. The data is provided by the buyer or owner of the machines. For this additional service, Gämmerler charges based on a payper-use model. We might infer from the publicly available data that Gämmerler, being the producer of the machines, can technically control the flow of data. This de facto control of the data 'can be a source of differentiation and competitive advantage for manufacturers'. ${ }^{18}$ To further illustrate this point, let us assume a third party would like to offer the monitoring service. This competitor needs (scenario 1 ) access to at least the data generated by the individual machines or (scenario 2 ) access to the aggregated usage data of a large number of machine users. Let us further assume a buyer of the machines would like to switch from Gämmerler's service to the competitor's offer and that the general terms in the sales and/or services contract regarding the upkeep and maintenance of the machines (not the additional smart services) prohibit the buyer and eventual owner of the machines from allowing third parties to access the private application programming interfaces implemented by Gämmerler. Thus, the manufacturer cannot only de facto control the flow of data but has contractually allocated itself a legal title to prevent the buyer from accessing the data. That is the competitive advantage of the manufacturer with regard to the downstream services market. This advantage is exacerbated by the fact that user data cannot or only with difficulty be obtained by means other than direct collection from the machine user.

In 2017 the Commission entertained the idea of solving this problem through the implementation of default contract terms: They 'could describe a benchmark balanced solution for contracts relating to data' and 'could be coupled with introducing an unfairness control in B2B contractual relationships which would result in invalidating contractual clauses

16 European Commission (n. 13) $\operatorname{COM}(2017) 9$ final, 9.

17 Acatech (ed), 'Wegweiser Smart Service Welt' (April 2017) $11<$ www.acatech.de/w p-content/uploads/2018/03/acatech2017_SSW_Wegweiser_de_bf.pdf $>$ accessed 31 August 2020.

18 European Commission (n. 13) $\operatorname{COM(2017)~} 9$ final, 10. 
that deviate excessively from the default rules'. Additionally, 'they could also be complemented by a set of recommended standard contract terms designed by stakeholders'. ${ }^{19}$

\section{Disadvantages of a purely self-regulatory approach}

It appears that this combined approach is no longer pursued by the Commission. Instead, the Commission focuses primarily on self-regulatory instruments 'with freedom of contract as a cornerstone'. ${ }^{20}$ The Commission postulated five key principles that should be respected in contractual agreements: (1) transparency, (2) shared value creation, (3) respect for each other's commercial interests, (4) ensuring undistorted competition and (5) minimising data lock-in. ${ }^{21}$ One of the centre pillars of this self-regulatory approach is the code of conduct. ${ }^{22}$ An example is Article 6 Regulation 2018/1807/EU on a framework for the free flow of non-personal data within the European Union ${ }^{23}$ under which the Commission 'shall encourage and facilitate the development of self-regulatory codes of conduct at Union level [...], in order to contribute to a competitive data economy', including 'best practices for facilitating the switching of service providers and the porting of data in a structured, commonly used and machine-readable format'.

I am rather sceptical regarding the effectiveness of a purely self-regulatory approach in the data economy. Especially large companies often rely on as little intervention as possible and can thus - thanks to a much more integral setup - profit from the uncertainties of the individual regulatory regimes. Consequently, it does not surprise me that stakeholders of the data within the data economy share the opinion that it still is too early for horizontal legislation on data sharing in business-to-business relations. ${ }^{24} \mathrm{At}$ this point in time most stakeholders cannot securely forecast where they would end up in a more regulated framework: on the favoured or on the regulated side. Thus, it is only rational for them to object to an introduction of a broad horizontal regulation at this time. Meanwhile, established

19 European Commission (n. 13) $\operatorname{COM}(2017) 9$ final, 12.

20 Communication of the European Commission, 'Towards a common European data space' $\operatorname{COM}(2018) 232$ final, 9.

21 European Commission (n. 20) $\operatorname{COM}(2018) 232$ final, 10.

22 European Commission (n. 20) $\operatorname{COM}(2018) 232$ final, 10.

23 [2018] OJ L 303/59.

24 European Commission (n. 20) $\operatorname{COM}(2018) 232$ final, 9. 
stakeholders may go back to using one-sided general terms, which they will then combine with technical access controls in order to fortify their market position.

The governance models relating to the mobility of data generated and collected by the 'connected car' are a prime example of how non-intervention works, or rather: does not work. The example also shows that the theoretically separated regimes of personal data as laid down in the GDPR ${ }^{25}$ and non-personal machine-generated data in practice regularly overlap when information is extracted. ${ }^{26}$ Even if the regulatory focus is on machine-generated data, a modern approach to the data economy has to integrate the perspective of privacy-based data protection as well. ${ }^{27}$ There are two basic models of data governance regarding smart cars: ${ }^{28}$ In the 'external server' solution, all in-vehicle data is transmitted to an external server outside the car. The server provides sole access to the data. The 'extended vehicle' concept of the European automobile industry ${ }^{29}$ is a variant of this solution, because the data is stored on a proprietary server of the original equipment manufacturer, who will exercise exclusive control of the data. Another variation of this 'centralisation of in-vehicle data' 30 model is the 'shared server' concept. Here, the server is not under the exclusive control of the automobile manufacturer but is governed by a third party that must grant access to the data stored on the server to other stakeholders on nondiscriminatory terms and within the regulatory framework of the GDPR. The competing technological solutions are known as the 'in-vehicle interface' and the 'on-board application platforms'. In both conceptions the data is stored in the car itself; the models can be distinguished solely by where the data analysis is executed, outside the vehicle system or inside the

25 Regulation 2016/679/EU of the European Parliament and the Council of 27 April 2016 on the protection of natural persons with regard to the processing of personal data and on the free movement of such data, and repealing Directive 95/46/EC (General Data Protection Regulation) [2016] OJ L119/1.

26 See Axel Metzger, 'Digitale Mobilität - Verträge über Nutzerdaten' (2019) Gewerblicher Rechtsschutz und Urheberrecht 129, 131.

27 Josef Drexl, 'Legal Challenges of the Changing Role of Personal and Non-Personal Data in the Data Economy' in Alberto de Franceschi and Reiner Schulze (eds), Digital Revolution - New Challenges for Law (C.H. Beck and Nomos 2019) 19, 20.

28 For a detailed analysis, see Wolfgang Kerber, 'Data Governance in Connected Cars' (2018) 9 Journal of Intellectual Property, Information Technology and ECommerce Law 310.

29 See $<$ www.cardatafacts.eu $>$ accessed 31 August 2020.

30 Communication of the European Commission, 'On the road to automated mobility: An EU strategy for mobility of the future' $\operatorname{COM(2018)} 283$ final, 13. 
vehicle environment. ${ }^{31}$ In both cases it is the car owner's decision to allow access to the data stored within the car, by granting access to the vehicle itself. The car manufacturers' preference for the centralised model is rather unsurprising, as is their 'compromise' solution to grant neutral service providers access to their servers. ${ }^{32}$ Once again, 'the technological solution determines the initial allocation of the de facto exclusive control of data and thus the initial allocation of the de facto "ownership" of data'. ${ }^{33}$ To make matters worse from a competition point of view, the manufacturer most likely acquires the end-user's consent in processing the personal data according to Article 6(1)(a) GDPR with the scope of consent potentially being tailored to address the specific needs of the manufacturer while excluding competing parties. The manufacturer is in a monopolistic gatekeeper position because she can determine whether and under what conditions the users of the vehicles and third parties can access the data relevant to them, consequently limiting or eliminating competition on aftermarkets and complementary services. ${ }^{34}$ Also, rather unsurprisingly, the Commission in 2018 was still sceptical whether this model would be sufficient to ensure fair and undistorted competition. ${ }^{35}$

\section{Putting unfair terms control back on the stage}

After all, regulation is required. The discussion mainly revolves around two competing policy approaches: ${ }^{36}$ Does general competition law entail the necessary and appropriate regulatory instruments or should the competition authorities be granted new instruments to tackle the complex issues in the data economy rather than pursuing a sector-specific approach with tailored data governance solutions? Most recently, the Commission has advocated for a cross-sectoral governance framework for data access and use

31 Mike McCarthy and others, 'Access to In-vehicle Data and Resources' (TRL Study, May 2017) 32-45 <https://ec.europa.eu/transport/sites/transport/files/2017-05-acce ss-to-in-vehicle-data-and-resources.pdf $>$ accessed 31 August 2020.

$32<$ www.cardatafacts.eu/vehicle-data-available-service-providers/> accessed 31 August 2020.

33 Kerber (n 28) para. 19.

$34 \operatorname{Kerber}$ (n. 28) paras 24-28.

35 European Commission (n. 30) $\operatorname{COM(2018)~} 283$ final, 13.

36 See Josef Drexl 'Connected devices - An unfair competition law approach to data access rights of users', in this volume. 
by introducing new horizontal measures. ${ }^{37}$ In particular, it outlined the possibility of a Data Act in 2021 to provide incentives for horizontal data sharing between (private) actors and across sectors. ${ }^{38}$ However, the Commission still adheres to the general principle of freedom of contract and voluntary data sharing. ${ }^{39}$ Access to data should be made compulsory only on a sector-specific level and, additionally, 'if a market failure in this sector is identified/can be foreseen, which competition law cannot solve'. ${ }^{40}$ Contract law and the unfairness control appears to have slipped out of sight. I would like to put it back in the spotlight. ${ }^{41}$ I build on the Commission's suggestion of 2017 to combine standard contract terms with a robust unfairness control. This is a contribution to the 'debate as to how contract law, including unfair contract terms control, can be developed further in order to create the right incentives and support parties in reaching fair and efficient data access regimes'. ${ }^{42}$

37 Communication of the European Commission, 'A European strategy for data' $\operatorname{COM}(2020) 66$ final, 12.

38 European Commission (n. 37) $\operatorname{COM}(2020) 66$ final, 13.

39 European Commission (n. 37) $\operatorname{COM}(2020) 66$ final, 13.

40 European Commission (n. 37) $\operatorname{COM}(2020) 66$ final, 13 note 39.

41 The German Data Ethics Commission argues in the same direction; see Opinion of the Data Ethics Commission, 'Gutachten der Datenethikkommission' (October 2019) $146<$ www.bmi.bund.de/SharedDocs/downloads/DE/publikationen/themen /it-digitalpolitik/gutachten-datenethikkommission.pdf?_blob=publicationFile\&v =6> accessed 31 August 2020: 'Insofar as a contractual legal relationship already exists, the principles of fair data access can be taken into account above all by way of the (possibly supplementary) interpretation of the contract - for example by accepting corresponding contractual ancillary obligations - as well as by way of the unfairness control regarding the general terms and conditions of business according to Sec. 307 German Civil Code)'.

42 Neil Cohen and Christiane Wendehorst, 'ALI-ELI Principles for a Data Economy, ALI Council Draft No. 1' (8 December 2019), 'Reporter's notes on Principle 16' 70 (on file with author). 


\section{An (additional) regulatory instrument: unfairness control in B2C and B2B data contracts}

\section{The proposition}

\section{Unfairness control as a data access rule}

The main argument of this paper is rather simple, maybe too simple. My thesis is that the unfairness control of general terms and conditions is a suitable regulatory instrument for, first, establishing adequate access rules in multilateral contract networks and, second, effectively enforcing individual access rights of end-users.

Access rule (Zugangsregel) is an umbrella term of a sociological conception of copyright law to develop legal mechanisms for the system-specific coordination of exclusivity on the one hand and user freedom on the other hand. ${ }^{43}$ Access rules 'fix the conditions under which users enjoy the freedom to use protected material without depending on the permission of the right holder'. ${ }^{44}$ They 'prevent the exercise of rights to intellectual goods from undermining the necessary conditions for the creation of those goods. In short, access rules decentralize the authority to select the use of an intellectual resource. [...] This way, they preserve the environmental conditions of knowledge-sharing in social systems'. ${ }^{45}$ Accordingly, ' $[t]$ he search for limitations of IP rights within the legal system itself is thus to be characterized as an "ecological" question, for it is ultimately aimed at the system's relationship with its environment'. ${ }^{46}$ The term is, to oversimplify an elaborated argument, a specific counter term (Gegenbegriff) to copyright's exclusive (property) rights. By taking into account 'the multilateral social effects of IP rights', ${ }^{47}$ access rules provide a framework capable of designing a balanced regulatory system enabling knowledge sharing with various other social systems. The term addresses 'the epistemological dimension of property rights'. ${ }^{48}$

This functional dimension of 'access rules' is not limited to exclusivity created by (legal) property rights, but applies to any exclusivity with regard

43 Dan Wielsch, Zugangsregeln (Mohr Siebeck 2008) 31 et seq.

44 Dan Wielsch, 'Private Governance of Knowledge: Societally-Crafted Intellectual Properties Regimes' (2013) 20 Indiana Journal of Global Legal Studies 907, 928.

45 Ibid. 929.

46 Ibid. 930.

47 Ibid. 925.

48 Ibid. 
to information, ${ }^{49}$ therefore including de facto exclusivity through technological means. This is why the term and its underlying legal theory play an important role in the data context, too. As explained above, the regulatory problem is precisely the combination of the technologically generated $d e$ facto exclusivity backed by the contractual normativity of the data controller's authority over the data. ${ }^{50}$ It is important to note that the de facto control is a standard employed within a specific societal functional system: the technological subsystem. Moreover, it is the contract that provides a normative foundation to this social standard or practice. Because " $\mathrm{p}]$ rivate law provides the normative instruments to make social standards binding and enforceable' it follows that it is also the responsibility of private law to 'promote, as well as put limits on, the jurisgenerative force of standards' ${ }^{51}$ In our case such responsibility is assigned to contract law, because it is the contract with the data holder that provides the prima facie justification of the social standard.

To summarise: By 'access rules' I refer to instruments of contract law exercising normative power over the data holder's de facto control over the machine-generated data. Because the data holder secures her de facto exclusivity through contract, it becomes the responsibility of contract law to check on the legal force of the technological standard by applying an unfairness control to the terms at issue. That is why the unfairness control functions as an 'access rule'. Access rules can, under certain circumstances, condense into subjective access rights. This is the case if the contractual terms and conditions fail to meet the unfairness test requirements. Then the contract will turn against the data holder: The technological de facto standard with respect to exclusivity is in violation of normative standards of contract law regarding the usability of the data at issue. Thus, the contractually assigned allocation is void. As a consequence, the normative pillar of the private data governance system has collapsed. Hence, the facticity of the data holder's control of the data not only lacks a normative justification but runs afoul of contract law's principles regarding fair data allocation and access to co-generated data. To remedy the normative deficit of the facticity regarding data control, contract law demands that data access

49 The terms 'information' and 'data' should generally be distinguished; see Zech (n. 4) 51, 53-54. However, de facto control of the raw data includes the control of this particular encoding of information as well and it is very unlikely that exactly the same information is encoded in other raw data. Therefore, de facto control over data obstructs the flow of information.

50 See sections A. and B. I. above.

51 Wielsch (n. 44) 925. 
be reallocated to the other party. As a result, contract law has to provide for a contractual claim of the end-user against the other party to actively enable access to individual-level data generated by the end-user or within the end-user's responsibility. Furthermore, the end-user may transfer the exercise of this access right to a third party..$^{52}$

\section{Premises}

This argument is based on three premises.

a) Methodological framework: responsive private law theory

The first premise is my methodological framework. The argument is built upon a consequence-oriented, regulatory ${ }^{53}$ or, more accurately: 'responsive' 54 conception of private law. The main methodological idea behind responsive law $^{55}$ is to 'translate' social theories of, for example, economic, sociological, or philosophical nature into law. It is important to note that responsiveness informs the law on the multitude of functional systems in its environment, each of which follows its own inner logic and each of which can raise its own normative claims. Furthermore, economic social theories should not enjoy preferential treatment, but the various other different social spheres of autonomy are of equal priority and must be treated with equal respect by the law as well. An exclusively economic focus does not do justice to this task of law. ${ }^{56}$ Responsive law, first, requires the legal doctrine to treat the descriptions of its environment provided by social theories as productive irritations. Second, the law must reconstruct the insights gained by those social theories within the legal system and using its own concepts and terms. Finally, it shall 'react' to these irritations by using a

52 See section D. I.

53 For an in-depth account see Alexander Hellgardt, Regulierung durch Privatrecht (Mohr Siebeck 2016).

54 For a detailed account see Michael Grünberger, 'Responsive Rechtsdogmatik' (2019) 219 Archiv für die civilistische Praxis 924. My conception has been heavily influenced by Gunter Teubner, Law and Social Theory: Three Problems (transl. Alison Lewis, Ancilla Iuris 2014) 135.

55 Locus classicus: Philippe Nonet and Philip Selznick, Law and Society in Transition: Towards responsive law (Routledge 1978).

56 Teubner (n. 54) 183, 190. 
more suitable construction of legal norms and concepts, in order to be able to adequately address the various needs of the different functional systems in its environment. This irritation process is productive in the sense that the law enables itself to adequately react to the social embedding of (private) law. One could also speak of a 'multilateralism of private law institutions'. ${ }^{57}$

I therefore understand law as a specific social practice and consider the conflicts to be resolved by law primarily based on their respective social context. In this sense the responsive law approach is environmentally sensitive. ${ }^{58}$ With regard to the specific (power) dynamics in the data economy I plead for a more economic, a more technological and a more sociological approach. In particular, I advocate for abandoning the traditional division of labour within private law, according to which contract law is limited to governing the interests within the bilateral legal relationship, while all the irritations of the functional conditions of this relationship are assigned to competition law. ${ }^{59}$ Competition law in the digital age has had a tendency to take effect too late to significantly alter the rules of the game. Contract law has to step up and fill the regulatory void left by an inadequately tailored competition law. ${ }^{60}$ Compared to competition law, judicial control of unfair terms might be profitable for SMEs and consumers in order to timely protect their legitimate interests. ${ }^{61}$ Also, contract law is much more flexible in balancing conflicting interests in a multitude of applications. Additionally, responsive contract law must integrate two perspectives: the quest for an efficient and data-trading-enhancing market regulation must be balanced with the requirements of a privacy-based data protection regime ${ }^{62}$.

57 Dan Wielsch, 'Die Vergesellschaftung rechtlicher Grundbegriffe' (2018) 38 Zeitschrift für Rechtssoziologie 304.

58 Groundbreaking Wielsch (n. 43) 31 et seq.

59 Michael Grünberger, 'Verträge über digitale Güter' (2018) 218 Archiv für die civilistische Praxis 213, 245.

60 For further analysis why competition law does not offer sufficient solutions, see Drexl (n. 10) 36-37, but see Heike Schweitzer and Robert Welker 'A legal framework for access to data - A competition policy perspective', in this volume.

61 Gerald Spindler, 'Data and Property Rights' (2017) 9 Zeitschrift für Geistiges Eigentum 399, 402.

62 Drexl (n. 27) 19, 20. One could add a third concern, the data holder's legitimate interest in securing her trade secrets as protected by Directive 2016/943/EC on the protection of undisclosed know-how and business information (trade secrets) against their unlawful acquisition, use and disclosure [2017] OJ L157/1. However, I would argue that this is an element that is crucial for the efficient functioning of data markets and is, therefore, 'built in' in the first prong. 
In particular, contract law doctrine must resist the temptation to tame the restrictions provided by data protection law by referring back to traditional contractual means. It shall not, for example, limit or impact the exercise of the data subject's withdrawal right under Article 7(3) GDPR if the data subject has entered into a contract regarding the supply of digital content and digital services by providing data to the trader under Article 3(2) Digital Content Directive. ${ }^{63}$

b) General regulatory framework of the data economy

A regulatory conception of contract law requires a regulatory framework. Josef Drexl has developed a regulatory theory for the data economy, identifying four objectives that should be understood from a perspective of public interest and be considered simultaneously: (1) establishing a functioning and competitive market for the data economy; (2) promoting innovation; (3) protecting consumer interests with a particular focus on protecting the privacy of natural persons; and (4) promoting additional public interests. ${ }^{64} \mathrm{He}$ argues that this regulatory theory reflects 'the constitutional framework of fundamental rights in its entirety [and] provides a comprehensive theory for assessing regulation of the economic economy from a justice perspective'. Based on this claim he urges scholars and regulators to dismiss recommendations 'based on pure justice arguments without being capable of being explained against the backdrop of this regulatory theory'. ${ }^{65}$ Although I hesitate to subscribe to the two latter statements, which are unnecessarily broad, I can agree with the relevance of the four elements outlined above within a responsive law theory.

I will not further elaborate on the first two objectives, because all relevant aspects have been laid out already ${ }^{66}$ Regarding the third objective I would like to clarify that for my analysis the regulatory goal should not be limited to consumer interests, but include (business) interests of non-consumer entities, in particular SMEs, as well. The fourth prong is of particular importance to responsive contract law in view of it raising awareness for the contract's societal functions. I think that both interests highlighted

63 Directive 2019/770/EU of the European Parliament and the Council of 20 May 2019 on certain aspects concerning contracts for the supply of digital content and digital services [2019] OJ L136/1.

64 Drexl (n. 10) 48-59; see also Drexl (n. 27) 19, 20.

65 Drexl (n. 10) 50.

66 For a detailed analysis, see Drexl (n. 10) 51-53. 
by Drexl, the freedom of information and the legitimate governmental interest to gain access to privately held data, are important examples of the grounds of public interest. ${ }^{67}$ Having expressed my desire to emphasise that there are additional aspects to be considered by a responsive law approach, I will first take notice of the negative social effects of the (aggregated) individual exercise of private autonomy. One example is the 'unraveling effect' occurring when some of the data subjects exercise their subjective right by giving consent to data collection, whereas others refuse to do so. ${ }^{68}$ This exercise of private autonomy by a few will eventually pressure others into adjusting their behaviour:

Everyone may eventually discover, however, that they have little choice. At first, those with positive private information (the 'top' of the pool) will disclose to seek discounts and economic benefit and to defend against the negative effects of the digital dossier. Eventually, even those with the worst private information (the 'bottom' of the pool) may realize that they have little choice but to disclose to avoid the stigma of keeping information secret. ${ }^{69}$

Thus, individual consent, as heralded by both data privacy and contract lawyers does 'not capture the behavioral pressure associated with unraveling ${ }^{70}$ and might not be the best fit for the collective good. This argument has been further developed into a concept of 'data pollution', which 'invites us to expand the focus and examine the ways the collection of personal data affect[s] institutions and groups of people - beyond those whose data is taken'. ${ }^{71}$ The law has to be aware of this additional negative externality since the 'participation of people in data-harvesting services affects others, and the entire public'. ${ }^{72}$ Therefore, the unfairness control must not limit itself to the interests of the parties involved, but take into consideration negative external effects of data access as well.

67 Drexl (n. 10) 56-58 limits his account to these two grounds.

68 Scott Pepper, 'Unraveling Privacy: The Personal Prospectus and the Threat of a Full-Disclosure Future' (2011) 105 Northwestern University Law Review 1153, 1176-1182; Yoan Hermstrüwer, 'Contracting Around Privacy' (2017) 8 Journal of Intellectual Property, Information Technology and E-Commerce Law 9, paras 2128.

69 Pepper (n. 68) 1176.

70 Hermstrüwer (n. 68) para. 25.

71 Omri Ben-Shahar, 'Data Pollution' (2019) 11 Journal of Legal Analysis 104, 106.

72 Ben-Shahar (n. 71) 106. For an illuminating example see Hermstrüwer (n. 68) para. 12. 


\section{c) Specific regulatory framework for contractual data access rules}

Designing access rules through contract law requires looking beyond the bidirectional contractual relationship of two parties and understanding the multilateralist nature of data governance structures. 'In complex processes of data generation - understood in a broader sense, including different phases of data production, data enrichment and data refinement - several actors with differing goals often interact with each other and contribute to the generation of data in different roles. ${ }^{73}$ However, the facticity of data co-generation by multiple actors is entangled with the de facto allocation of powers to one actor only by virtue of her control over the technical infrastructure.

This is the challenge of implementing data-governance structures: Should a normative order accept the status quo's facticity, or should it reign it in, and, if so, how shall this be done? The German Data Ethics Commission has been supportive of a normative order, supplementing the facticity of the current data economy. ${ }^{74}$ Based on the co-generation processes it pleads for 'data-specific rights of co-determination and participation, which in turn may lead to corresponding obligations on the part of other parties' ${ }^{75}$ 'From an ethical point of view, therefore, a dynamic special relationship develops between an actor who was involved in the generation of data and an actor who de facto controls this data. ${ }^{76}$ It has developed five criteria for the recognition and design of data rights and corresponding data obligations in dynamic environments, among them the data holder's duty to grant access to data: '(1) the nature and scope of [the access-seeking] party's contribution to data generation, (2) the weight of that party's legitimate interest in being granted the data right, (3) the weight of any possibly conflicting interests on the part of the other party or of third parties, taking into account any potential compensation arrangements (e.g. protective measures, remuneration), (4) the interests of the general public, and (5)

73 Data Ethics Commission (n. 41) 85.

74 Data Ethics Commission (n. 41) 85-94.

75 Data Ethics Commission (n. 41) 85; quote taken from Data Ethics Commission, 'Opinion of the Data Ethics Commission' (English executive summary) 8-9 $<$ www.bmi.bund.de/SharedDocs/downloads/EN/themen/it-digital-policy/datenet hikkommission-abschlussgutachten-kurz.pdf;jsessionid=06B302BE9C6688059CC 584A27ED59F0F.2_cid364?_blob=publicationFile $\& v=2>$ accessed 31 August 2020.

76 Data Ethics Commission (n. 41) 85. 
the balance of power between the parties involved'. ${ }^{77}$ If data access will be granted through an unfairness control - and the Data Ethics Commission has approved of this approach - the requirements outlined above will provide an additional framework for designing adequate access rules.

\section{The benchmark and the knowledge problems}

\section{The lack of a statutory default rule}

The unfairness control of general terms requires a legal benchmark for what shall be considered a fair term. According to the standard established by Article 3(1) Unfair Terms Directive, ${ }^{78}$ a contractual term 'shall be regarded as unfair if, contrary to the requirement of good faith, it causes a significant imbalance in the parties' rights and obligations arising under the contract, to the detriment of the consumer'. 'Article $3[\ldots]$ merely defines in a general way the factors that render unfair a contractual term that has not been individually negotiated. ${ }^{79}$ The Court of Justice of the EU (CJEU) has established a division of labour in cooperation with national courts, which assigns the competence to determine whether a contractual term is 'unfair' to the national courts. ${ }^{80}$ German law has established that a contractual term unreasonably disadvantages the other party and is, thus, to be considered unfair, if it is, inter alia, 'not compatible with essential principles of the statutory provision from which it deviates' (Sec. 307(2)(1) German Civil Code). Supplementary provisions of national law (dispositives Vertragsrecht) serve as the main benchmark for the unfairness test. Contractual terms reflecting provisions of national law are generally excluded from the scope of the unfairness control (Article 1(2) Unfair Terms Directive $^{81}$ ) if it can be presumed that the national legislature struck an ap-

77 Data Ethics Commission (n. 41) 85-86; quote taken from the English executive summary (n. 75) 9.

78 Directive 93/13/EEC [1993] OJ L95/29.

79 CJEU, Case C-243/08 Pannon GSM Zrt. v. Erzsébet Sustikné Gyórfi ECLI:EU:C:2009:350, para. 37.

80 CJEU, Case C-137/08 VB Pénzügyi Lizing Zrt. v. Ferenc Schneider ECLI:EU:C:2010:659, para. 47.

81 CJEU, Case C-92/11 RWE Vertrieb AG v. Verbraucherzentrale Nordrhein-Westfalen e.V. ECLI:EU:C:2013:180, paras 27-30. 
propriate balance between all rights and obligations of the parties within certain contracts. ${ }^{82}$

At the moment, national law lacks specific supplementary provisions regulating data access. This is a challenge for the unfairness control. It has been argued that it 'is necessarily dependent on the availability of supplementary provisions in contract law (dispositives Vertragsrecht) that can be used as a benchmark for an appropriate contractual balance of interests' ${ }^{\prime}{ }^{83}$ Due to the lack of a legal benchmark, courts would be at a loss to determine the fairness of contractual terms. It has been argued that corresponding default contract rules would need to be adopted before extending the unfairness control to data access rights. ${ }^{84}$ With the notable exception of personal data governed by the GDPR and the Directive on digital goods, 'the European legislature still has a long and possibly rocky road ahead of it in the development of an optional common European contract law for the data economy in the B2B-sector'. ${ }^{85}$ This situation is aggravated by the fact that designing statutory default rules requires knowledge of the data markets as well as their probable evolvements. The task of designing default contract statutes for the data economy faces the same fundamental challenge as any regulatory attempt: the knowledge deficit of state actors. This squaring of the circle is also the main reason for academics to be cautious of premature interventions. ${ }^{86}$ To put the argument in a nutshell: The unfairness control should not be part of the regulatory toolbox, due to a lack of supplementary statutory law. This results from a shortcoming of knowledge regarding the data economy. A broad government interference using general contract law would, at this time, most likely fail to adequately address the intricacies of different developing markets and could therefore not be justified.

82 CJEU, Case C-260/18 Kamil Dziubak and Justyna Dziubak v. Raiffeisen Bank International $A G$, ECLI:EU:C:2019:819, para. 59.

83 Josef Drexl, 'Neue Regeln für die Europäische Datenwirtschaft? Ein Plädoyer für einen wettbewerbspolitischen Ansatz - Teil 2' (2017) Neue Zeitschrift für Kartellrecht 415, 420 (emphasis added).

84 Drexl (n. 10) 38 .

85 Drexl (n. 83) 420.

86 See Axel Metzger, 'Access to and porting of data under contract law: Consumer protection rules and market-based principles', in this volume. 


\section{The vocation of our digital age for legal science}

I have a rather different vision 'of the vocation of our age for legislation and legal science'87. I think that the cautious 'We-Don't-Know-It-WellEnough-To-Regulate-It' approach of some voices in legal academia will eventually make matters worse. We should be aware that the status quo of the data economy can be compared to the Wild West: If we start regulating after the big stakeholders have secured their claims there is little left to be effectively regulated. However, the lack of knowledge has to be taken seriously. I believe that the procedural model presented in this paper adequately addresses it by relying on both the production and, subsequently, the judicial acquisition of private knowledge in various industry sectors while, at the same time, implementing normative instruments that continuously irritate the private order in a productive way. One size doesn't fit all. The increasing support for a sector-specific regulatory approach and for sector-specific data access rights ${ }^{88}$ has evidential value for this statement. Therefore, it does make sense to leave the initial decision regarding the fairness of contractual terms up to the stakeholders involved in the concerned sectors. Normative governance structures must then ensure that the voices of all stakeholders regardless of their market power and, in addition, the viewpoints of agents of public interests, will be heard.

The unfairness control is structurally capable of reflecting the necessary distinctions. First, the established enforcement mechanisms regarding the unfairness control, representative actions for the protection of collective interests and, in Germany, unfair competition law proceedings can be deployed as effective instruments of knowledge acquisition in the data economy. Second, the court procedure provides a forum to the parties who, as agents of the conflicting social functions of data exclusivity vs. data access, shape the discussion of what is to be deemed 'unfair'. Third, for any decision, being but case law, it can - depending on the jurisdiction - rather easily be overruled in new cases after more complex information has been extracted. This is why the unfairness control is a flexible tool that belongs in the regulatory toolbox.

87 The reference to Friedrich Carl von Savigny, Vom Beruf unserer Zeit für Gesetzgebung und Rechtswissenschaft (Heidelberg, 1814), is intended.

88 See Josef Drexl, 'Connected devices - An unfair competition law approach to data access rights of users', in this volume; Wolfgang Kerber, 'From (horizontal and sectoral) data access solutions - Towards data governance systems', in this volume; Heike Schweitzer and Robert Welker, 'A legal framework for access to data - A competition policy perspective', in this volume. 


\section{Statutory default rules are not required}

The argument against unfair terms control based on the lack of statutory benchmarks is surprisingly unimaginative and state-centered. It starts from the wrong, or at least, an incomplete premise. The unfairness control is not necessarily dependent on the availability of supplementary provisions in contract law. Still, it is true that default contractual rules could constitute benchmarks for a standard contract terms control. ${ }^{89}$ They are, however, not the only imaginable benchmarks. Section 307(2)(2) of the German Civil Code provides additional standards: the 'essential rights or duties inherent in the nature of the contract [may not be limited] to such an extent that attainment of the purpose of the contract is jeopardised'. To put it pointedly: A fairly balanced contract law practice within the data economy could deliver the benchmark for individual contracts. It is too shortsighted to focus only on the legislature for establishing benchmarks. The best approach is to incentivise the individual and/or collective actors in the data economy to draft and make use of model contract clauses ${ }^{90}$ or codes of conduct. ${ }^{91}$ This will be the focus of the next chapter.

The second-best solution for the benchmark problem is to rely on model agreements developed by legal academics with a fairness approach in mind. The ALI-ELI Draft Principles for a Data Economy ${ }^{92}$ meet the criteria. ${ }^{93}$ They could not only be conducive 'to facilitate the drafting of model agreements $[\ldots]$ by parties in the data economy' (Principle (1)(e)), but also 'be used as a source of inspiration and guidance for the further development of the law by courts' (Principle (1)(b)). The Principles contain 'data rights', that is, 'rights that a party has against a controller of data arising from the nature of the data and its generation' (Principle 15(1)), including 'the right to be provided access to data or port data' (Principle 15(1)(2)(a)).

89 European Commission, 'Staff Working Document on the free flow of data and emerging issues of the European data economy' SWD (2017) 2 final, 32.

90 This appears to be the approach of the European Commission, too; see European Commission (n. 13) 12; European Commission (n. 20) 10-11.

91 This is part of the new Commission's sectoral data strategy regarding 'data spaces': see European Commission, 'A European strategy for data' (Communication) $\operatorname{COM}(2020) 66$ final, 30-32.

92 'ALI-ELI Principles for a Data Economy, Preliminary Draft No. 3' (15 October 2019) (on file with author). Henceforth I will cite the most recent Draft available to me: the ALI Council Draft No. 1 version of 08 December 2019 (n. 42).

93 For an introduction, see Christiane Wendehorst, 'The ALI-ELI Principles for a Data Economy' in Alberto de Franceschi and Reiner Schulze (eds), Digital Revolution - New Challenges for Law (Munich, 2019) 41. 
These rights are justified by fairness considerations (Principle 15(3)), which are based on the fact that the party had a share in the generation of the data at stake. ${ }^{94}$ Principles 17 through 19 provide further guidance regarding the factors and criteria for establishing a data access right of one party: Article 17 of the Principles lists three factors that should be taken into account when determining (access) rights to co-generated data:

(1) the extent to which that party is the subject of the information coded in the data, or is the owner of the object of that information;

(2) the extent to which the data was generated by an activity of that party, or by use of a device in which that party had ownership or any similar property rights; or

(3) the extent to which the data was generated by use of a computer program or other relevant component of a device in which that party holds intellectual property rights or in whose development that party has made investment.

Article 19 of the Principles contains an exemplary list of grounds that may give rise to a right to access: (1) the normal, foreseeable use, including resale, by the user of the commodity, (2) for quality monitoring, (3) for establishing facts of the party's own operations, (4) for developing new business models by a party with additional safeguards to protect the legitimate interests of the data holder/controller, and (5) to avoid lock-in effects, such as switching suppliers for a service. Finally, Article 18 of the Principles requires a general balancing exercise between (1) the factors established by Articles 17 and 19, respectively, (2) the legitimate interests of the data holder/controller, (3) the bargaining power between the parties and (4) the public interests.

\section{A procedural model for the unfairness control}

As explained above, I claim that the unfairness control of general terms is a suitable regulatory instrument for, first, establishing adequate access rules in multilateral contract networks and, second, to effectively enforce individual access rights of end-users. ${ }^{95}$ As previously discussed, the unfairness control requires a suitable benchmark. ${ }^{96}$ The best benchmark for the un-

94 Cohen and Wendehorst (n. 42) 66.

95 See section C. I. 1.

96 See sections. C. II. 1 . and 2. 
fairness control is the collective knowledge gathered by the private actors. The process of gaining such knowledge with the help of private ordering is at the core of my proposal to create a contract-law-based access rule for the data economy. This benchmark is provided by model contracts. However, not every model contract will suffice. It must meet a certain standard of (procedural) justice as fairness. In the following Section I will propose a both regulated and self-regulatory approach applying the unfairness control to the data economy. This is a solution based on the cooperation between private knowledge production, private standardisation and private rule-making on the one hand ('self-regulation') and governmental (framework) regulation on the other. Governmental regulation reacts to the pressure of making decisions under conditions of uncertainty by tying in with methods and models employed by non-state actors intended to acquire knowledge. This knowledge production occurs within the private law arena, allowing hypotheses to be formulated and tested and regulations to be implemented step by step, anticipating the production of new knowledge by the economic and/or technological systems affected by these regulations. ${ }^{97}$

\section{a) Rebuttable presumption of fairness}

At the core of this model is a (rebuttable) presumption that contractual standard terms are not unfair in the sense of Section 307(1)(1) German Civil Code if they are an integral part of model contracts, codes of conduct or best practices that in turn are compliant with certain requirements of procedural justice. If the presumption is successfully rebutted, the accessrestricting contract clause is unfair and therefore invalid. ${ }^{88}$ The normative pillar justifying the de facto control of the data holder has crumbled and the ongoing de facto control and the refusal to grant access to the relevant data is no longer tolerable. To remedy the normative deficit of the facticity regarding data control, contract law requires data access to be reallocated to the other party by granting her a right to access the data against the data holder. The latter party must authorise the former party's access to the par-

97 See Karl-Heinz Ladeur, 'Die Regulierung von Selbstregulierung und die Herausbildung einer "Logik der Netzwerke" in (2001) Regulierte Selbstregulierung als Steuerungskonzept des Gewährleistungsstaates. Die Verwaltung, Beiheft 4, 59, 76.

98 See Art. 6(1) Unfair Terms Directive. 
ticular data or a particular data source ${ }^{99}$ governed by the unfair contractual term and must, depending on the technological design of her de facto control, enable this party to effectively access this data. For example, the data holder must open the private application programming interfaces, thus allowing data transfer to the other party.

\section{b) Role model I: equitable remuneration scheme in copyright law}

This model is influenced by standards providing equitable contractual remuneration for copyright licensing contracts. ${ }^{100}$ Under Section 32 German Copyright Act, each author has a right to the contractually agreed remuneration in return for exploitation rights. If the contractually agreed remuneration is not equitable, the author is entitled to sue the other party to consent to a modification of the agreement ensuring that the author eventually receives equitable remuneration (Section 32(1)(3) Copyright Act). There are three stages to establish whether the agreed remuneration is equitable. ${ }^{101}$ The first stage is to identify whether there are relevant collective bargaining agreements. If this is the case, the author's remuneration is solely determined by this instrument and she does not have a claim to adjust the remuneration set forth in the bargaining agreement (Section 32(4) Copyright Act). However, in most cases we are either lacking such agreements or the exploitation is outside their scope. Second, the contractually agreed remuneration is irrefutably (!) deemed equitable if it is covered by a joint remuneration agreement, established between authors' associations

99 This remedy has been inspired by Art. 10 ALI-ELI Principles for a Data Economy; see Cohen and Wendehorst (n. 42) 60-64.

100 Art. 18 of Directive 2019/790/EU of the European Parliament and the Council of 17 April 2019 on copyright and related rights in the Digital Single Market and amending Directives 96/9/EC and 2001/29/EC [2019] OJ L130/92 has recently harmonised the principle of appropriate and proportionate remuneration of authors and performing artists. Member States remain free to use different implementation mechanisms (Art. 18(2) of the Directive), and Recital 73 clarifies that these instruments may include collective bargaining and other (collective) mechanisms.

101 See BGH (Federal Supreme Court), 21 May 2015 - GVR Tageszeitungen I (Joint Remuneration Agreement Daily Newspapers I), (2016) Gewerblicher Rechtsschutz und Urheberrecht 62, para. 13 (sketching out the three steps); BGH (Federal Supreme Court), 15 November 2016 - GVR Tageszeitungen III (Joint Remuneration Agreement Daily Newspapers III), (2016) Gewerblicher Rechtsschutz und Urheberrecht 1296 (fine-tuning the prerequisites for each step). 
on one and associations of exploiters of works or individual users of works on the other side (Sections 32(2)(1) and 36(1) Copyright Act). The determination of appropriateness of the joint remuneration agreements applies also to non-members of the associations. Third, if neither collective bargaining nor joint remuneration agreements are directly applicable, the courts must determine whether the contractually agreed remuneration corresponds to what is customary and fair in comparable business relations, given the nature of the exploitation of copyright protected subject matter by the licensee and the extent to which exploitation can possibly be granted, particularly in terms of duration of the licensing agreement, the specifics of the exploitation, and considering all remaining circumstances (Section 32(2)(2) Copyright Act). Courts may seek guidance from joint remuneration agreements covering the same forms of exploitation even if they are not directly applicable. ${ }^{102}$ The equitable remuneration scheme in German copyright law is purposefully designed to provide incentives for joint remuneration agreements. ${ }^{103}$ By establishing an irrefutable presumption, the law privileges a self-regulatory model over an individual judicial decision assessing the equity of the remuneration. The law assumes, first, that the joint agreement bundles the knowledge of a social practice and, second, that it adequately balances the competing interests of authors and exploiters. Consequently, the joint remuneration agreement will most likely yield better results than an individual assessment of a court.

It is precisely this nexus that is at the core of the unfairness model developed in this paper. By introducing a presumption of fairness if the contractual terms are in line with exemplary rules concerning access in the data economy, contract law refers to the knowledge gained within the regulated system and by the relevant actors within this system. However, differing from the Copyright Act's precedent, the presumption in my model shall be rebuttable. There are two reasons for this deviation: First, the Copyright Act has to answer the question of how to establish a fair and equitable remuneration, whereas the unfairness control applies 'neither to the definition of the main subject matter of the contract nor to the adequa-

102 BGH (Federal Supreme Court), 21 May 2015 - GVR Tageszeitungen I (Joint Remuneration Agreement Daily Newspapers I), (2016) Gewerblicher Rechtsschutz und Urheberrecht 62, para. 16 (holding that the remuneration criteria set forth in a joint remuneration agreement for newspaper journalists can also be used as a benchmark if the conditions for their application are not (fully) fulfilled and therefore do not have an irrefutable presumption of conformity).

103 Karl-Nikolaus Peifer in Ulrich Loewenheim, Ansgar Ohly and Matthias Leistner (eds), Schricker - Urheberrecht (6 ${ }^{\text {th }}$ edn, C.H.Beck 2020) \36 UrhG para 46. 
cy of the price and remuneration' (Article 4(2) Unfair Terms Directive). Assessing the iustum pretium is notoriously difficult for a court to achieve. Thus, it is advantageous for a court to rely on applicable joint remuneration agreements without having to second-guess its ability to balance the interests appropriately. Following this train of thought, my model has to exempt the core of the contractual agreement from judicial review. Second, unlike the situation in the copyright remuneration issue, we are at the very beginning of designing governance rules for the data economy. Although it is most likely that a privately dominated process of gaining knowledge will yield superior results, it might be wise to design a system with built-in normative checks and balances regarding the fairness of the solutions found. The possibility to rebut the presumption of fairness exerts normative pressure on the private order to continuously re-evaluate and adapt the solutions presented in the model rules. Hence, it is a regulatory tool to further improve the societal knowledge-gaining process.

\section{c) Procedural requirements}

The solution presented by the Copyright Act is informative for a second reason. The prevalence of joint remuneration agreements over an individual judicial assessment and its extension to 'outsiders' requires that self-regulatory model of knowledge gaining to meet certain procedural criteria: The associations signing such agreements must be representative, independent and empowered to establish such joint remuneration agreements (Section 36(2) Copyright Act). ${ }^{104}$ The law can refer to the results of private ordering only if it can rightfully be assumed that all relevant perspectives, interests and stakeholders are represented in the process of gaining societal knowledge. On a procedural level, this is why the model developed here must ensure that the model contracts, best practices or code of conduct actually reflect a sufficiently widespread, appropriate and fair social practice. That is not a small challenge.

The European Commission has presented normative guidelines ${ }^{105}$ that are intended to foster fair and open data markets. The ALI-ELI Principles for a Data Economy ${ }^{106}$ and the propositions of the German Data Ethics

104 For a detailed analysis, see Peifer (n. 103) paras 52-62.

105 European Commission (n. 20) 10.

106 Cohen and Wendehorst (n. 42); see section C. II. 3. 
Commission ${ }^{107}$ provide a normative framework that could be used as a starting point for private ordering instruments. However, the model presented here requires actual model contracts or best practices within the data economy. Those have to be found and evaluated. The Support Centre for Data Sharing (SCDS) could solve this issue. ${ }^{108}$ The European Commission has assigned the SCDS the task to "provide practical advice, best practices and methodologies for data sharing and data analytics. For example, the platform will give access to model contract clauses tested in previous data transactions and backed by public authorities'. ${ }^{109}$ The SCDS has so far collected and classified twelve model contract terms used for datasharing purposes. ${ }^{110}$ The effort is laudable, although the licensing contracts analysed by the SCDS are far from helpful for solving my benchmark problem, because the contracts at issue do not cover the relevant industrial sectors. The same holds true for the data-sharing practice examples collected by the SCDS. ${ }^{111}$ The examples listed on the website are apparently chosen rather arbitrarily, do not follow a structuring pattern and are not of critical-analytical, but rather affirmative-descriptive nature. To conclude: The SCDS's resources are not suited to deliver the knowledge necessary in order for my unfairness model to work.

\section{d) Role model II: the (German) Corporate Governance Code}

I doubt that we could start solving my model's benchmark problem on the European level. Instead, I propose a bottom-up approach. The governments of the Member States should set up commissions consisting of all relevant stakeholders and agents of the public interests. They should assign these commissions the task of identifying and fostering best practices as well as drafting a code of conduct regarding data sharing. Insofar we can learn from a rather successful example displaying a combination of private

107 Data Ethics Commission (n. 41) 85-92; see section C. I. 2. c) above.

$108<$ https://eudatasharing.eu/about-us > accessed 31 August 2020.

109 European Commission, 'Annex to the Commission Implementing Decision on the adoption of the work programme for 2018 and on the financing of Connecting Europe Facility (CEF) - Telecomunications Sector' C(2018) 568 final, 42.

110 SCDS, B.1 - Report on collected model contract terms (26 July 2019) <https://eu datasharing.eu/sites/default/files/2019-10/EN_Report\%20on\%20Model\%20Contr act\%20Terms.pdf $>$ accessed 31 August 2020.

$111<$ https://eudatasharing.eu/data-sharing-practice-examples $>$ accessed 31 August 2020 . 
knowledge gaining (self-regulation) and proper regulation: the German Corporate Governance Code. It illustrates the mutual irritation between autopoietic societal subsystems. ${ }^{112}$

(1.) The Corporate Governance Code identifies social practices in the economic system and sets them up as an optional (normative) standard of behaviour. It therefore formulates legal rules of a special kind: behavioural appeal and informal recommendations, without any claim of binding force or sanctions, in short: a regulatory offer to the subsystem (= corporation). (2) The individual corporation accepts this recommendation by implementing it within its organisation and setting normative standards regarding legal and economic communications. If the corporation does not integrate the recommendations, the standardised social regulation of the economic system remains ineffective within the corporate subsystem. If the subsystems fail to follow the Code by the dozen, the Code will be forced into new learning processes which improve the communications within the corporate subsystems. The Code perceives this refusal as new, additional knowledge and will subsequently adapt the recommendations to the willingness to accept it, for it does not want to call its overall acceptance into question. (3.) The management board and the supervisory board of a company listed on the stock exchange must annually declare that the Code's recommendations have been and are being complied with, or which of the Code's recommendations have not been applied or are not being applied and the reasons therefore (Section 161(1) German Stock Corporation Act). This is traditional hard law. With the options given to the corporation, hard law facilitates the learning process in the economic system. The corporation has to inform its environment of which of the three explanation variants it has chosen. The hard law does not contain a presumption in favour of the Code's recommendation in the legal system. However, the mutual interference between law and economics is not taken into account if the recommendations are being qualified as non-binding 'food for thought' only. This could also be achieved through an opt-in rule. However, Section 161 Stock Corporation Act is designed as an optout rule: It is not the compliance but the deviation that must be justified. The law thus takes on a substantive position. It adopts the view that the Code's recommendations are in fact the best practice of listed companies. Thus, Section 161 recommends compliance with the rule without making it compulsory. Obligations to give reasons and justify the deviation, how-

112 Michael Grünberger, 'Geschlechtergerechtigkeit im Wettbewerb der Regulierungssysteme' (2012) 3(1) Rechtswissenschaft 31-33. 
ever, result in encouraging conduct in conformity with the rule. As soft law, this standard thus ensures that the recommendations of the Commission become the default rule.

\section{Problems}

\section{Privity-of-contract problem}

The main objection against the use of the unfairness control to secure data access rights is the theory of privity of contract (Relativität der Schuldverhältnisse): Following the traditional principle of relative effect of contracts the proposed contract law solution 'only works where the person interested in access and the data holder enter into a direct contractual relationship. However, such direct relationship does not always exist'. ${ }^{113}$ There are two prevailing situations in which a lack of direct contractual relationship between the data holder/controller and the party requiring data access becomes apparent: (1) The direct purchaser and owner of the data-gathering device leases or sells it to a third party. 'Under the principle of privity of contract, the contractual right of access to the data will not travel with the property in the used device. ${ }^{114}$ (2) A third party requires data access in order to provide data-related services to the party which has or had a contractual relationship with the data holder. In comparison, a statutory data access right applies without the need for a direct contractual relationship with the producer or supplier of the intelligent product, and, in addition, such statutory regulations generally cannot be waived by the entitled person, thus being more likely to produce adequate results. ${ }^{115}$

This argument is based on the premise that the privity-of-contract doctrine strictly limits contractual rights and duties to the parties of the contract. This is, at least regarding German civil law, not the case: 'The isolation of creditor and debtor in the contractual relationship, the isolation from "the rest of the world", is no longer satisfying. Therefore, the contractual relationship is increasingly extended by third-party effects. A consider-

113 Drexl (n. 9) 38.

114 Josef Drexl and others, 'Position Statement of the Max Planck Institute for Innovation and Competition of 26 April 2017 on the European Commission's "Public consultation on Building the European Data Economy", 7 <ww.ip.mpg.de/ fileadmin/ipmpg/content/stellungnahmen/MPI_Statement_Public_consultation _on_Building_the_EU_Data_Eco_28042017.pdf $>$ accessed 31 August 2020.

115 Drexl (n. 83) 420. 
able number of them take account of particular social ties which extend beyond the legal microcosm of the contractual obligation.' ${ }^{116}$ Whether such third-party effects are possible and desirable and how they should be designed is, following traditional German doctrine, a question that might be answered differently over time and depending on the specific regulatory issues to be addressed. ${ }^{117}$ In the digital and networking economy we are faced with the pressing question whether the economic and/or technological connections can also be legally re-constructed by assuming a network effect in the various contractual relationships at issue or at least by establishing a quasi-contractual connection. ${ }^{118}$ I would argue that the construction of third-party effects can be a suitable regulatory instrument in contract law. They are building blocks of an environmentally sensitive data contract law.

I will briefly sketch my argument to demonstrate that contract law can effectively be used for tailored access rights responding to the parties' individual needs that can also be exercised by a third party. In reference to the model presented here, the other party has a data access right based in her contract with the data holder if the contractual terms concerning data usage between her and the data holder is unfair. ${ }^{119}$ In order to safeguard the effectiveness of this remedy, any contractual waiver of this right that has not been individually negotiated is an unfair term and, therefore, void. The data access right can be transferred to a third party. ${ }^{120}$ However, any third party will only get access to the individual-level data generated by the machines and not to the aggregated usage data of a large number of machine users. If the transfer of title should be excluded in the contract with the data holder/controller and if this term has not been individually negotiated, it shall, in general, be deemed unfair as well, because it is a further restriction of the effectiveness of the other party's remedy. If the data-gathering device is transferred to a third party (lessee, buyer or service provider), it shall be assumed through interpretation of the contractual arrangement with this party that she will also be assigned the data access right rooted in the first contract. If the data access right entails access to

116 Dieter Medicus, 'Drittbeziehungen in Schuldverhältnissen' (1974) Juristische Schulung 613.

117 Joachim Gernhuber, Das Schuldverhältnis (Mohr Siebeck 1989) 461.

118 For a detailed analysis, see Lukas Firsching, Vertragsstrukturen des Erwerbs einheitlicher IoT-Produkte (Duncker \& Humblot 2020).

119 See section C. I. 1.

120 Secs 398, 413 German Civil Code allow for the transfer of rights by the right holder to a third party through assignment. 
personal data as well, the third party must be able to justify the data processing in accordance with the requisites established in Article 6(1) GDPR.

\section{Transnational dimension}

The model developed in this paper could be applied to B2C contracts within every EU Member State. With regard to B2B transactions, only a few Member States have enacted a robust unfair terms control, Germany among them. However, the criticism against the wide scope of application of the unfair terms control has recently been increasing. The 'Coalition Agreement' between the three governing parties in Germany declares that the parties 'will review the law on general terms and conditions for contracts between companies with the aim of improving legal certainty for innovative business models'. ${ }^{121}$ It will not be surprising that in my learned opinion, the unfair terms control is central to the normative monitoring and effective governance of data-driven business models.

\section{E. Conclusion}

The real shortcoming of the model presented here is the fact that it securely applies only to national circumstances, whereas the data access issues are very often transnational issues. The problem can be solved within $\mathrm{B} 2 \mathrm{C}$ relations. If the consumer has her habitual residence in Germany, the German unfair terms control will apply (Article 6(1) Rome I Regulation). ${ }^{122}$ If the contract has a choice-of-law clause, the German consumer will still enjoy the protection by the mandatory unfair terms control (Article 6(2) Rome I Regulation). This picture significantly shifts in B2B relations. Due to the exercise of party autonomy (Article 3(1) Rome I Regulation), or, in absence of a choice-of-law clause, applying the objective connecting factors set forth in Article 4(1)(a) and (b) Rome I Regulation, foreign law will be applicable in many cases. One possible, and, I must admit, a bit far-fetched solution for saving the unfair terms data access model is to construct it as

121 Koalitionsvertrag zwischen CDU, CSU und SPD für die 19. Legislaturperiode (2018) <www.cdu.de/system/tdf/media/dokumente/koalitionsvertrag_2018.pdf?fi le $=1$, line 6186> accessed 31 August 2020.

122 Regulation (EC) 593/2008 of the European Parliament and of the Council of 17 June 2008 on the law applicable to contractual obligations (Rome I) [2008] OJ L177/6. 
an overriding mandatory provision in the sense of Article 9 Rome I Regulation. If one does not follow this suggestion, and, in view of the lack of EU harmonisation, the suitability of the unfair terms control as a regulatory instrument is indeed severely limited.

In the ongoing competition - perhaps even battle - for supremacy between the two opposing legal paradigms in the data economy (ownership and control vs. access) this paper pleads for access. I have presented a model to utilise the unfair terms control to design an access rule to effectively govern legitimate access to data in the data economy. The contractual unfairness control functions as an access rule which might develop into an access right. It partially removes the de facto allocation of data and its contractual justification by, first, restricting the data holder's (manufacturer's or service provider's) freedom of contract to include respective general terms and conditions and, second, by enabling the other party technological access to the data. The purpose of this paper was to demonstrate that the unfair terms control is, in its initial premises, a suitable regulatory instrument. If it is properly designed, it will foster knowledge gaining and sharing by private ordering, thus providing courts and legislatures with the necessary insights to adequately address the data access issues now. This paper does not present a complete account of the model and it does not address all of the possible objections, for example to the assignability of the access right. It serves the sole purpose of sketching out a path for the role of legal science to respond to conditions of uncertainty by designing creative legal tools. 